\title{
Taxonomic Composition and Biomass of Zoobenthos in Saline Lake Shira: Shifts That Happened in 65 Years
}

\author{
Alexander P. Tolomeev ${ }^{a}$, Svetlana P. Shulepina ${ }^{b}$, \\ Olesia N. Makhutovaa,b, Alexander V. Ageev', \\ Anton V. Drobotova and Nadezhda N. Sushchik ${ }^{* a, b}$ \\ anstitute of Biophysics SB RAS, \\ FRC "Krasnoyarsk Science Center SB RAS" \\ 50/50 Akademgorodok, Krasnoyarsk, 660036, Russia \\ ${ }^{b}$ Siberian Federal University \\ 79 Svobodny, Krasnoyarsk, 660041, Russia
}

Received 08.11.2016, received in revised form 18.11.2016, accepted 22.11.2016, published online 08.02.2018

\begin{abstract}
In summer 2016 we studied biomass and species composition of zoobenthos in saline Lake Shira that has large recreational significance for Khakasia and Krasnoyarsk regions. Zoobenthos of the studied lake consisted of 15 species, among those chironomid larvae Glyptotendipes salinus, Chironomus nigrifrons and Chironomus halophilus, and necto-benthic amphipod Gammarus lacustris dominated. Biomass values averaged for the studied summer period (54 days) were $6.8 \pm 3.11 \mathrm{~g} / \mathrm{m}^{2}$ and $4.4 \pm 1.01 \mathrm{~g} / \mathrm{m}^{2}$, for Chironomidae and Gammaridae taxa, correspondingly. We found significant difference in dominant species biomass and the total production of chironomids between the littoral and the pelagial parts of the lake. We compared our data with results of the only extensive study of zoobenthos in the lake that was carried out in the early fifties of $20^{\text {th }}$-century. The amphipod G. lacustris dominated in zoobenthos in that time, like in the contemporary period. In contrast, chironomid species that dominate now were not found in benthic fauna 65 years ago. Meanwhile, biomass values of Chironomidae and G. lacustris decreased in several times compared to zoobenthos values in fifties of the previous century. In general, relatively few number of benthic species in Shira Lake agrees with a common notion that species richness decreases in inland waters with salinity $>15 \%$. Averaged biomass of the dominant taxa, Chironomidae family, corresponded to a range of values reported for other saline water bodies.
\end{abstract}

Keywords: saline lake, zoobenthos, Chironomidae, spatial distribution, long-term changes.

(c) Siberian Federal University. All rights reserved

This work is licensed under a Creative Commons Attribution-NonCommercial 4.0 International License (CC BY-NC 4.0)

* Corresponding author E-mail address: labehe@ibp.ru 

and biomass of zoobenthos in saline Lake Shira: shifts that happened in 65 years. J. Sib. Fed. Univ. Biol., 2018, 11(4), $367-383$. DOI: $10.17516 / 1997-1389-0079$.

\title{
Характеристика таксономического состава и биомассы зообентоса соленого озера Шира: изменения, произошедшие за 65 лет
}

\author{
А.П. Толомеев ${ }^{a}$, С.П. Шулепина ${ }^{\tilde{\sigma}}$, О.Н. Махутова ${ }^{\mathrm{a}, \boldsymbol{\sigma}}$, \\ А.В. Агеев ${ }^{\sigma}$, А.В. Дроботов ${ }^{\text {a }}$ Н.Н. Сущик ${ }^{\text {a, }}$ \\ ${ }^{a}$ Институт биофизики СО РАН, \\ ФИЦ «Красноярский научный иентр СО РАН» \\ Россия, 660036, Красноярск, Академгородок, 50/50 \\ ${ }^{6}$ Сибирский федеральный университет \\ Россия, 660041, Красноярск, пр. Свободный, 79
}

В летний период 2016 г. исследована биомасса и видовой состав зообентоса соленого оз. Шира, имеющего большое рекреаџионное значение для Хакасии и Красноярского края. В составе зообентоса оз. Шира обнаружено 15 таксонов, среди которых доминировали личинки хирономид Glyptotendipes salinus, Chironomus nigrifrons и Chironomus halophilus, a также нектобентосные амфиподы Gammarus lacustris. Средние за исследованный период (54 суток) величины биомассы сем. Chironomidae и Gaтmaridae были $6.8 \pm 3.11$ и $4.4 \pm 1.01$ г/кв.м. Выявлены значительные различия в видовом составе, биомассе и продукичии хирономид, населяющих литоральную и профундальную части озера. Полученные данные сравнили с имеющимися в литературе сведениями о состоянии зообентоса этого озера в начале 50-х гг. ХХ в. Амифиподы G. lacustris доминировали в составе бентоса и ранее, тогда как современные доминирующие виды хирономид 65 лет назад отсутствовали. При этом значения биомассы сем. Chironomidae u G. lacustris в настоящее время снизились в несколько раз по сравнению с величинами, наблюдавшимися в 50-х г2. прошлого века. В иелом, относительно малое число видов бентоса оз. Шира соответствует современным представлениям о малом видовом разнообразии бентоса при солености внутренних вод свыше 15 \%. Средняя биомасса доминирующего сем. Chironomidae соответствовала диапазону значений, известных для прочих соленых водоемов и водотоков.

Ключевые слова: соленое озеро, зообентос, Chironomidae, пространственное распределение, многолетние изменения. 


\section{Введение}

Развитие лимнологии как научной дисциплины тесно связано с исследованиями конкретных водоемов, имеющих важное практическое значение для человека (Lake ecosystem.., 2010). Углубленные и регулярные исследования позволяют понять связь между особенностями функционирования экосистемы и полезными свойствами таких водных объектов, увеличивая фундаментальные знания и создавая научную основу рационального природопользования. Озеро Шира, рекреационный водоем, обладающий бальнеологическими свойствами, безусловно, является значимым объектом не для жителей только ближайших территорий (республика Хакасия, Красноярский край), но и более удаленных регионов России, благодаря известному минеральному курорту «Озеро Шира» с более чем 100-летней историей (Медикобиологические.., 1997).

К настоящему времени накоплено значительное количество фактического материала, касающегося функционирования экосистемы оз. Шира (Природный комплекс.., 2011; Gulati, Degermendzhy, 2002; Gulati et al., 2010), однако сведений о состоянии зообентоса (за исключением исследований планктобентосного вида Gammarus lacustris) практически нет. Нам известна лишь одна работа, характеризующая донную фауну озера, выполненная в начале 50-х гг. ХХ в. (Платонова, 1956). По данным Л.В Платоновой, доминирующими формами зообентоса по численности и биомассе являлись личинки хирономид (сем. Chironomidae, отр. Diptera), представленные родами Procladius и Polypedilum. Отсутствие внимания исследователей к донной фауне оз. Шира на протяжении длительного периода, вероятно, определялось традиционным подходом в изучении зообентоса как кормовой базы для рыб. Поскольку озеро на протяже- нии длительного периода наблюдений было безрыбным (Rogozin et al., 2011) (однако, по недавним данным, серебряный карась присутствует в зоне устья пресной реки), исследования были сосредоточены, главным образом, на элементах планктонной трофической сети (Gulati, Degermendzhy, 2002) и гидрофизических и гидрохимических факторах, объясняющих стратификацию меромиктического водоема (Degermendzhy et al., 2010). В результате зообентос оказался наименее исследованным компонентом данной экосистемы, а сведения о его современном состоянии отсутствуют.

Между тем знания о составе и динамике популяций донной фауны могут иметь значение не только для характеристики кормовой базы рыб, но и для понимания иных экосистемных взаимодействий. В последние десятилетия уделяется большое внимание роли бентосных беспозвоночных в минерализации оседающего органического вещества и рециркуляции биогенных элементов (Ji et al., 2011; Shang et al., 2013). Значительная доля исследований связана с использованием высокой чувствительности личинок хирономид к действию поллютантов, а также к изменениям условий окружающей среды (химических, температурных и др. факторов). Так, колебания численности или смена видового состава хирономид могут служить индикатором загрязнений либо признаком качественных изменений состояния экосистемы, что используется в палеолимнологических реконструкциях (Brodersen, Quinlan, 2006; Di Veroli et al., 2014).

Наконец, в последние десятилетия внимание исследователей к зообентосным сообществам, значительную долю которых нередко составляют популяции амфибионтных насекомых, связано с тем, что вылет имаго насекомых обеспечивает прибрежные эко- 
системы суши специфическими «субсидиями» водной продукции (aquatic subsidies). По некоторым глобальным оценкам основная часть общего потока органического вещества, производимого во внутренних водных экосистемах и попадающего в наземные трофические сети, обеспечивается именно вылетом имаго бентосных насекомых (Vander Zanden, Gratton, 2011; Bartels et al., 2012). Вылетающие амфибионтные насекомые нередко составляют значительную долю рациона наземных консументов, кормящихся в прибрежной полосе, таких как членистоногие, ящерицы, летучие мыши, насекомоядные птицы (Nakano, Murakami, 2001; Sabo, Power, 2002; Reimer et al., 2010; Stenroth et al., 2015), а также являются для них источником некоторых необходимых элементов и незаменимых биохимических веществ (Bartels et al., 2012; Gladyshev et al., 2013; Stenroth et al., 2015).

Исследования, выполненные в настоящей работе, связаны в основном с последним из перечисленных направлений - с определением роли амфибионтных насекомых в переносе незаменимых биохимических веществ, таких как полиненасыщенные жирные кислоты, из воды на сушу в аридных ландшафтах. Однако сведения о состоянии зообентоса могут быть также полезны для любых из указанных направлений исследований. Таким образом, целью работы стала оценка современного состояния зообентоса (прежде всего популяций хирономид) в оз. Шира, и сравнение с имеющимися данными, полученными 65 лет назад. Работа включала мониторинг пространственного распределения, видового состава, численности и биомассы зообентоса, а также анализ продукции доминирующих таксонов, Amphipoda и Diptera (сем. Chironomidae), в течение летнего периода 2016 г.

\section{Район работ, методы}

Озеро является солоноватым меромиктическим водоемом, площадь водного зер-

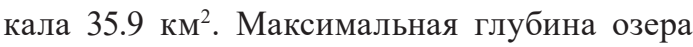
достигает 24 м, средняя глубина - 11.2 м. Минерализация колеблется в пределах 14-18 г/л, состав воды сульфатно-хлоридно-натриевомагниевый (Degermendzhy et al., 2010). В безледный период (май-ноябрь) характерна ярко выраженная температурная стратификация водной толщи. В осенний и весенний периоды озеро перемешивается лишь частично до глубины 9-12 м, в отдельные годы - до 15-16 м (Rogozin et al., 2010). Однако следует отметить, что в последние несколько лет происходило еще большее опускание нижней границы зимнего миксолимниона, а в 2015 г. зарегистрировано полное перемешивание водной толщи до глубины 24 м (Рогозин, 2015). Часть донных грунтов озера представлена грязевыми иловыми отложениями, средняя толщина слоя которых составляет 0.85 м (Природный комплекс..., 2011, с. 24), при этом иловые отложения в основном аноксигенные.

Пелагическая экосистема озера характеризуется небольшим видовым богатством и относительно малым числом трофических уровней. В летний период фитопланктон (доминируют преимущественно Cуanobacteria и Chlorophyta) имеет характерное вертикальное распределение с выраженным глубинным максимумом биомассы на горизонте 8-12 м (Gaevsky et al., 2002). Основными представителями зоопланктона являются рачки Arctodiaptomus salinus (Daday), коловратки Brachionus plicatilis (Müller) и Hexarthra oxyuris (Zernov). Важнейший компонент фауны - бокоплав Gammarus lacustris, относящийся как к нектонной, так и бентосной форме жизни (Zadereev et al., 2010). На большей части акватории оз. Шира ихтиофауна отсутствует, за исключением юго-восточной 
части, где близ устья пресной р. Сон отмечено эпизодическое присутствие серебряного каpacя Carassius auratus gibelio (Bloch) (Rogozin et al., 2011).

Пробы зообентоса собирали на 4-х станциях озера (рис. 1), на глубинах 1 и 6 м, в течение летнего периода, 8.06.2016, 23.06.2016, 10.07.2016, 1.08.2016. Грунты на литорали (глубина 1 м) и профундали (глубина 6 м) станции 1 представлены глинисто-иловыми отложениями; литораль и профундаль ст. 2 (северная часть озера) отличаются песчаными грунтами; грунты станции 3, расположенной в юго-восточной части озера, образованы черными илами, а на литорали - также дерниной; дно станции 4 разнородно и составлено каменистыми обломочно-сланцевыми породами и глиной (рис. 1). Для сборов проб использовали скребок Дулькейта (с площадью захвата 1/10 кв. м, только на литорали 8.06.2016) и дночерпатель Экмана-Берджи (с площадью захвата 1/50 кв. м, в остальные даты пробоотбора). Пробы промывали многократно через мельничный газ с размером ячеи 200 мкм. Затем в лаборатории живые организмы беспозвоночных (макрозообентоса) выбирали из пробы с помощью пинцетов и фиксировали в 80 \%-ном этаноле. При камеральной обработке проб бентосных животных разбирали по группам, учитывали численность и взвешивали на торсионных весах (тип WT) с дискретностью определения массы до 1 мг. Анализ таксономического состава (до личиночной группы) зообентоса проводили согласно сле-

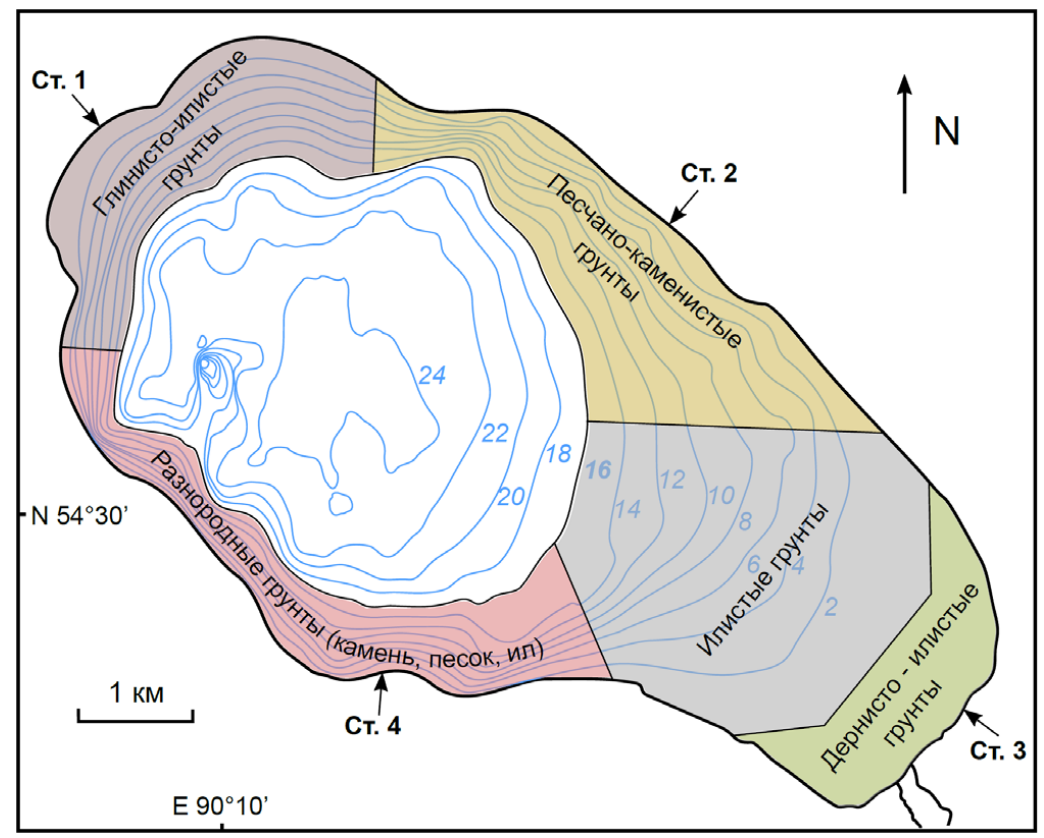

Рис. 1. Карта-схема оз. Шира (Хакасия, Сибирь) с указанием расположения станций сбора проб и типами грунтов. Границы между разными типами грунтов определены предварительно. Концентрические линии - глубины, м. Незакрашенная глубоководная часть соответствует аноксигенным грунтам с высоким содержанием сероводорода, непригодным для обитания личинок хирономид

Fig. 1. Map-scheme of Lake Shira (Khakassia, Siberia) with location of sampling sites and types of bottom sediments. The closed lines indicate lake depths. The boundaries between areas occupying with various sediment types were outlined tentatively. Uncolored deepest part of the lake has anoxigenic sediments with high content of reduced sulfur-containg compounds, and it is an unsuitable habitat for chironomids larvae 
дующим определителям (Панкратова, 1977, 1983; Определитель.., 1994, 1997, 1999). Для уточнения видовой принадлежности хирономид p. Glyptotendipes были собраны имаго выплодившихся самцов, далее морфологические признаки личинок и имаго оценивали согласно ключам (Contreras-Lichtenberg, 1999). Поскольку таксоны хирономид были определены только по морфологическим признакам, их идентификацию следует считать предварительной, с необходимостью дальнейшего исследования кариотипов хромосом.

В период с 8.06.2016 по 1.08.2016 температуру водной толщи в оз. Шира измеряли непрерывно, каждые 10 мин, с помощью автономных термисторных цепей, включающих цифровые температурные датчики DS18b20 (Maxim Integrated Products, США). Температура воды на глубинах 1 и 6 м на указанных станциях колебалась в пределах 16.1-24.4 и 12.3-22.5 ${ }^{\circ} \mathrm{C}$.

Суточную продукцию зообентоса вычисляли с использованием уравнений, связывающих продукцию особи (и популяции) со скоростью энергетического обмена и удельную скорость продукции с температурой (Голубков, 2000; Berezina, 2008). Продукцию за период наблюдений, составивший 55 сут для глубин 1 м и 40 сут для глубин 6 м, рассчитывали методом трапеций. Для возможности сравнения данных для глубин 1 и 6 м величины продукции были пересчитаны на 30-дневный период, отражавший «условный» летний месяц.

\section{Результаты}

Средние за исследованный летний период 2016 г. значения численности и биомассы отдельных видов макрозообентоса, а также частота их встречаемости по всей акватории озера приведены в табл. 1. На всех четырех станциях практически во все даты пробоот- бора присутствовали нектобентосные рачки Gammarus lacustris и личинки хирономид Polypedilum bicrenatum (табл. 1). Кроме того, личинки хирономид Glyptotendipes salinus, Chironomus halophilus и Chironomus nigrifrons встречались более чем в $30 \%$ coбранных проб. Помимо представителей отр. Amphipoda и Diptera (сем. Chironomidae) виды прочих таксонов встречались редко и (или) давали весьма небольшой вклад в общую биомассу зообентоса (табл. 1). На станциях 1 и 3 с илистыми грунтами основную часть биомассы макрозообентоса составляли виды сем. Chironomidae (63-76 \%), тогда как на станциях с песчаными или каменистыми грунтами (2 и 4) их вклад был заметно меньшим, 16-41 \% (табл. 1). Максимальная численность организмов зообентоса была на литорали ст. 1 за счет вклада мелких хирономид P. bicrenatum, высокая численность наблюдалась также в профундальной части ст. 3, прежде всего за счет вклада видов p. Chironomus (табл. 1).

Максимум биомассы зообентоса как в литорали, так и в профундали наблюдался на ст. 3, минимальная величина для литорали была на ст. 2, а минимум в профундали соответствовал ст. 4 (табл. 1). Следует отметить, что размах колебаний средней биомассы зообентоса по акватории озера в исследованный период 2016 г. был более чем 10-кратным, с минимальным значением на ст. 2, глубина 1 м, и максимальным - на ст. 3, глубина 6 м.

Состав и биомасса бентосных комплексов, приуроченных к разной глубине, были рассмотрены на трансекте ст. 3, 22 июня 2016 г. (табл. 2). На данной трансекте расстояние между глубинами 1, 3, 6, 10 и 16 м было 0.8, 0.6, 0.6 и 1 км, соответственно (рис. 1). Амфиподы G. lacustris были наиболее многочисленны на глубине 6 м, их биомасса здесь превышала таковую в прибрежье (1 м) более чем вчетверо (табл. 2). Рачки встречались и 


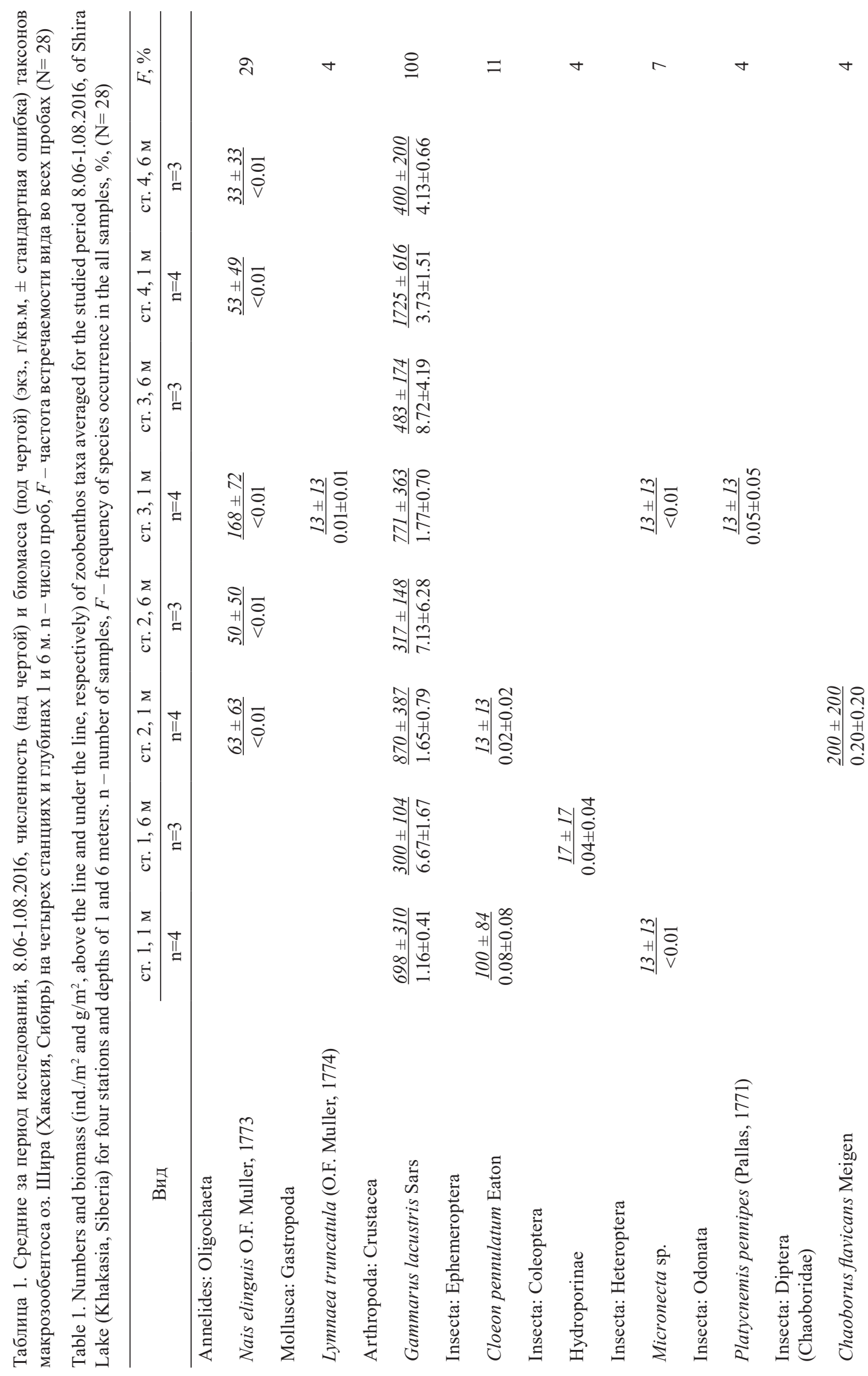


ปீ ๙

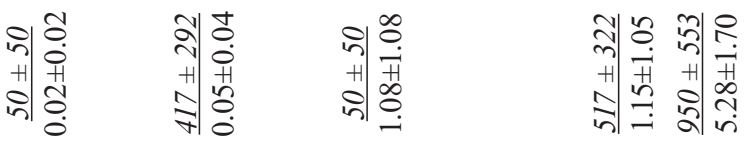

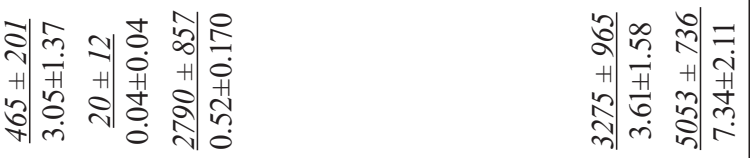

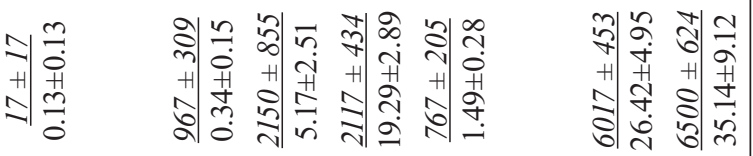

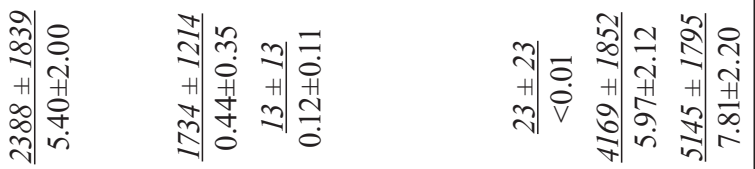

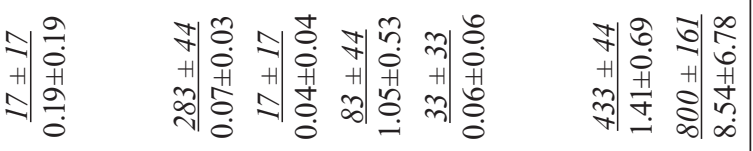

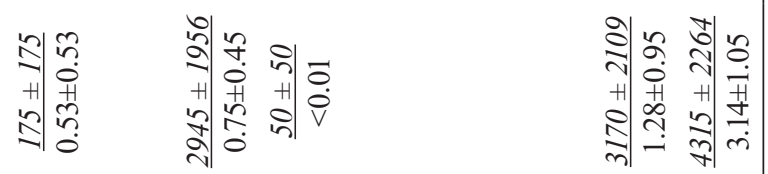

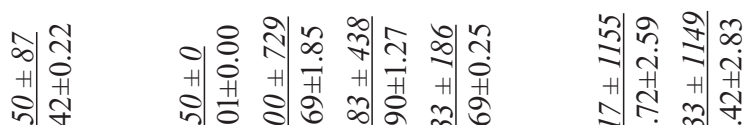

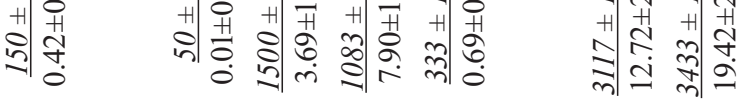

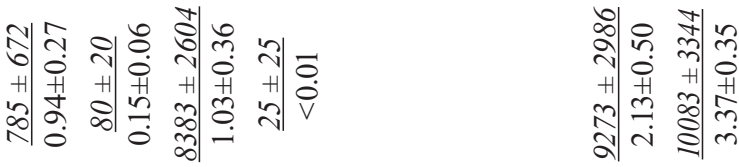

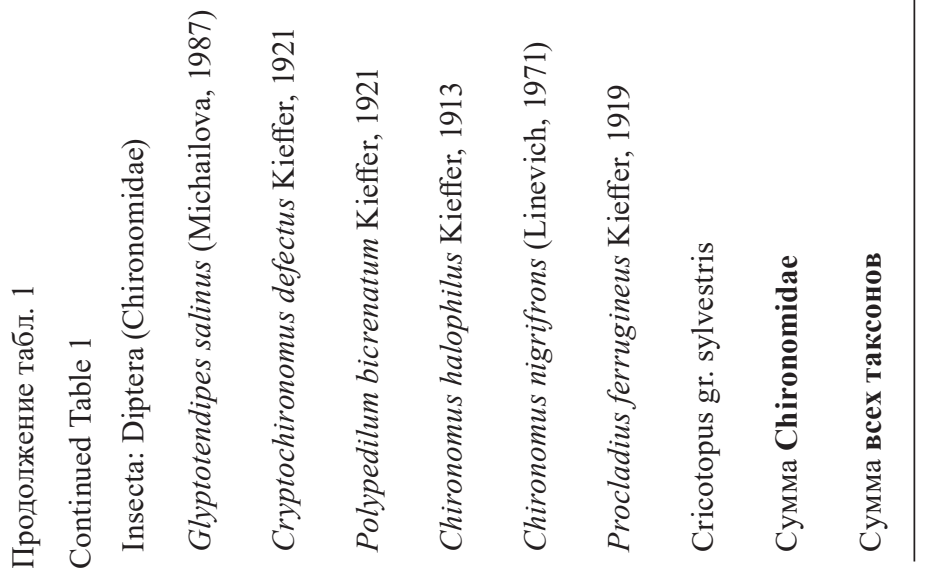


Таблица 2. Биомасса (г/кв.м, \pm стандартная ошибка, $\mathrm{n}=2$ ) таксонов зообентоса на трансекте станции 3 , 22.06.2016, оз. Шира (Хакасия, Сибирь)

Table 2. Biomass $\left(\mathrm{g} / \mathrm{m}^{2}, \pm\right.$ standard error, $\left.\mathrm{n}=2\right)$ of zoobentic taxa for a transect of sampling site 3, 22.06.2016, Shira Lake (Khakassia, Siberia)

\begin{tabular}{|c|c|c|c|c|c|}
\hline Вид & $1 \mathrm{M}$ & $3 \mathrm{~m}$ & $6 \mathrm{~m}$ & $10 \mathrm{M}$ & $16 \mathrm{M}$ \\
\hline \multicolumn{6}{|l|}{ Annelides: Oligochaeta } \\
\hline Nais elinguis & $<0.01$ & $<0.01$ & & & \\
\hline \multicolumn{6}{|l|}{ Arthropoda: Crustacea } \\
\hline Gammarus lacustris & $3.70 \pm 1.15$ & $3.58 \pm 1.08$ & $17.10 \pm 4.70$ & $0.90 \pm 0.90$ & \\
\hline \multicolumn{6}{|c|}{ Insecta: Diptera (Chironomidae) } \\
\hline Glyptotendipes salinus & $6.03 \pm 0.93$ & $3.00 \pm 2.20$ & - & & \\
\hline Polypedilum bicrenatum & $1.48 \pm 0.23$ & $0.88 \pm 0.33$ & $0.07 \pm 0.05$ & & \\
\hline Chironomus halophilus & $0.01 \pm 0.01$ & $0.03 \pm 0.03$ & $10.00 \pm 0.90$ & - & $0.10 \pm 0.10$ \\
\hline Chironomus nigrifrons & - & - & $25.00 \pm 7.00$ & - & - \\
\hline Procladius ferrugineus & $<0.01$ & - & $1.21 \pm 0.49$ & $0.12 \pm 0.12$ & - \\
\hline Сумма Chironomidae & $7.52 \pm 1.17$ & $3.90 \pm 2.50$ & $36.28 \pm 5.66$ & $0.12 \pm 0.12$ & $0.10 \pm 0.10$ \\
\hline Сумма всех таксонов & $11.22 \pm 2.32$ & $7.48 \pm 3.58$ & $53.38 \pm 0.96$ & $1.02 \pm 1.02$ & $0.10 \pm 0.10$ \\
\hline
\end{tabular}

на глубине 10 м, тогда как на 16 м отсутствовали. Личинки хирономид были обнаружены на всех глубинах, однако на 10 и 16 м - лишь единично. Сообщество хирономид на глубинах 1 и 3 м было представлено в основном видами $G$. salinus и $P$. bicrenatum, тогда как C. halophilus и C. nigrifrons составляли основную часть биомассы хирономид на глубине 6 м (табл. 2). Вид Procladius ferrugineus также массово встречался только на глубине 6 м. Следует отметить, что пик биомассы хирономид и общей биомассы зообентоса наблюдался на глубине 6 м, а на больших глубинах происходило резкое снижение биомассы бентоса до крайне низких значений на 16 м (табл. 2).

Сравнение значений биомассы часто встречавшихся видов зообентоса (6 видов Chironomidae и G. lacustris), усредненных по всей акватории озера, показало, что биомасca G. salinus и P. bicrenatum была достоверно выше для литоральной части озера (рис. 2). В свою очередь, профундаль озера характеризовалась достоверно большими величи- нами биомассы хирономид $C$. halophilus, $C$. nigrifrons, P. ferrugineus и рачка G. lacustris.

Средняя за исследованный период биомacca сем. Chironomidae, а также относительный вклад в нее массовых видов на всех изученных станциях и глубинах представлены на рис. 3. Видовой состав хирономид профундали и литорали различался на всех четырех станциях озера. Очевидно, что основной вклад в среднюю биомассу хирономид озера обеспечен видами C. nigrifrons и C. halophilus за счет профундальной зоны станций 1 и 3. Виды хирономид, приуроченные к литорали, по-разному распространены по акватории озера: G. salinus в основном встречается в грунтах южной и юго-восточной части озера (ст. 3 и ст. 4), тогда как биомасса P. bicrenatum больше на северо-западе озера, ст. 1 и ст. 2 (рис. 3).

Продукция амфиподы G. lacustris за период 30 дней (условный месяц летнего сезона) составила в среднем по водоему $1.2 \pm 0.28$ и $3.2 \pm 0.46$ г сырой массы / кв.м для глубин 1 и 


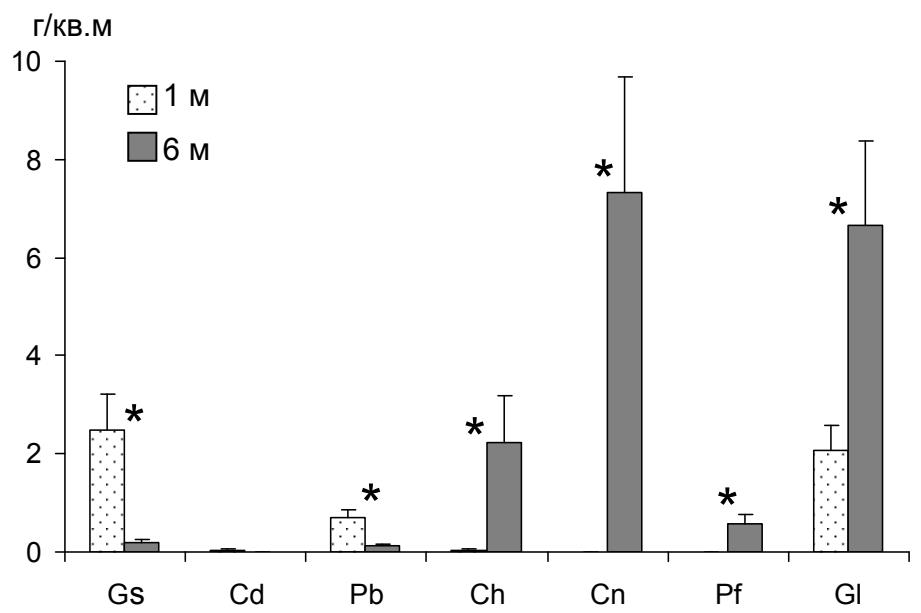

Рис. 2. Средние значения биомассы (г/кв. м, \pm стандартная ошибка) доминирующих видов зообентоса в пробах, собранных на 4 станциях оз. Шира (Хакасия, Сибирь) 08.06-1.08.2016. * Различия между величинами для литорали (1 м) и профундали (6 м) достоверны по t-критерию Стьюдента $(P<0.05)$. Gs - Glyptotendipes salinus, $\mathrm{Cd}$ - Cryptochironomus defectus, $\mathrm{Pb}$ - Polypedilum bicrenatum, $\mathrm{Ch}$ - Chironomus halophilus, $\mathrm{Cn}$ - Chironomus nigrifrons, Pf - Procladius ferrugineus, Gl - Gammarus lacustris

Fig. 2. Biomass ( $\mathrm{g} / \mathrm{m}^{2}$, means \pm standard errors) of dominant species in zoobentic samples averaged for 4 sampling sites, Shira Lake (Khakassia, Siberia), 08.06-1.08.2016. * Differences between values for littoral (1 meter depth) and profundal $(6$ meter depth) areas are significant after Student's t-test $(P<0.05)$. Gs - Glyptotendipes salinus, $\mathrm{Cd}$-Cryptochironomus defectus, $\mathrm{Pb}$ - Polypedilum bicrenatum, $\mathrm{Ch}$-Chironomus halophilus, $\mathrm{Cn}-$ Chironomus nigrifrons, Pf - Procladius ferrugineus, Gl - Gammarus lacustris

6 м соответственно. В свою очередь, суммарная продукция сем. Chironomidae за такой же летний период, усредненная для всей акватории, была $17.9 \pm 5.99$ и $46.2 \pm 13.89$ г сырой массы / кв.м для глубин 1 и 6 м соответственно. Очевидно, что основной вклад в продукцию бентоса изученного соленого озера составляли хирономиды, населяющие профундаль.

\section{Обсуждение}

При сравнении современного состояния зообентоса оз. Шира с данными, полученными при интенсивном исследовании этого водоема 65 лет назад (Платонова, 1956), очевидна следующая общая закономерность. Для озера характерен пик биомассы зообентоса в профундальной части как в давний период исследований, так и сейчас. Кроме того, максимумы биомассы зообентоса обнаружены на тех же станциях, что и в исследовании Плато- новой (1956), т.е. в восточной (ст. 3) и западной (ст. 1) частях озера (рис. 3). Возможно, это связано с морфологическими особенностями котловины (уклон дна на этих станциях относительно пологий), а также мощными накоплениями иловых отложений, особенно в восточной части. Вследствие морфологических особенностей (удаленность от сероводородной котловины) можно предполагать наличие оксигенных условий на значительной части профундали этих станций, что благоприятствует обитанию хирономид. Кроме того, большие запасы иловых отложений на профундали этих станций, вероятно, могут поддерживать успешное развитие хирономидных сообществ на протяжении многих десятилетий.

Однако нужно отметить, что средние величины биомассы сем. Chironomidae и Gammaridae по акватории, зарегистриро- 


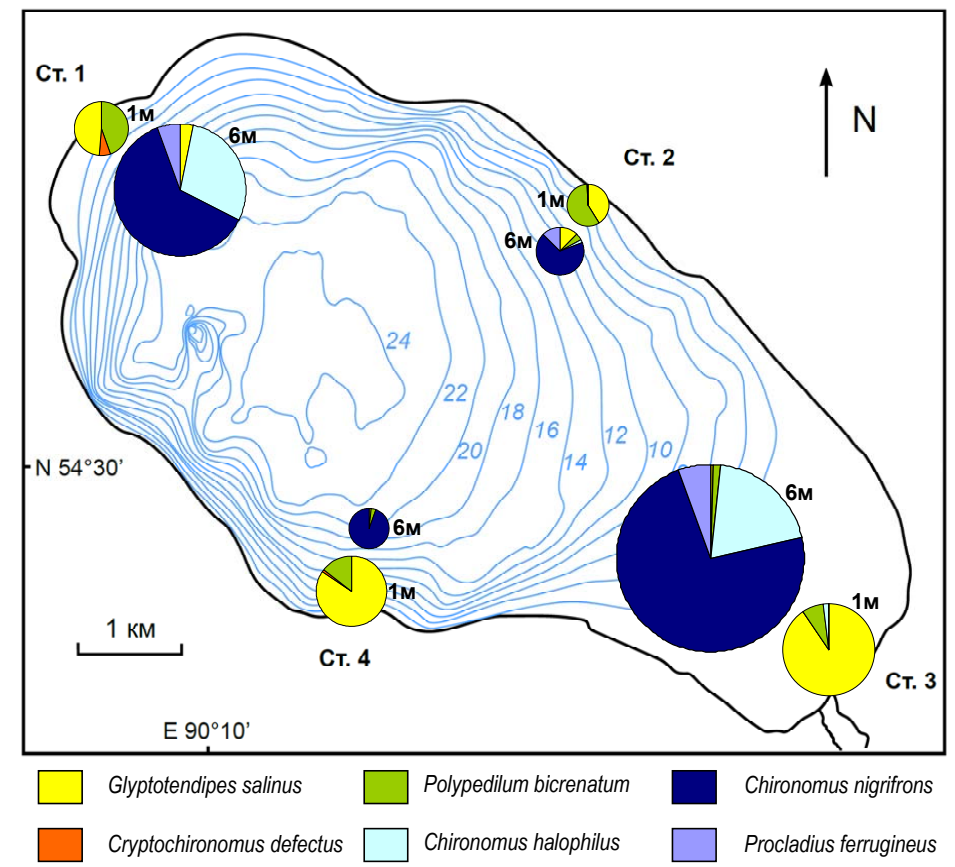

Рис. 3. Диаграмма процентного вклада видов хирономид в общую биомассу сем. Chironomidae на разных станциях и глубинах оз. Шира (Хакасия, Сибирь) 08.06.2016-1.08.2016. Площадь кругов пропорциональна средней биомассе хирономид на данной станции и глубине

Fig. 3. Diagram of per cents of chironomid species biomass of the total biomass of Chironomidae for studied sampling sites and depths, Shira Lake (Khakassia, Siberia), 08.06-1.08.2016. Circles' area is proportional to mean biomass of Chironomidae for a given sampling site and depth

ванные нами в июне-августе 2016 г., 6.8 и 4.4 г/кв.м, были в несколько раз меньше уровней биомассы соответствующих таксонов летнего бентоса в 50-х гг. прошлого века, 34 и 38 г/кв.м (Платонова, 1956). Что может быть причиной столь резкого падения биомассы двух ведущих таксонов бентосной фауны рассматриваемого соленого озера за прошедшие 65 лет? Во-первых, не следует исключать значительных межгодовых колебаний биомассы зообентоса, что служит характерной чертой многих водоемов.

Во-вторых, с 30-40-х гг. прошлого столетия происходит постоянный подъем уровня воды в озере (Rogozin et al., 2010; Darin et al., 2015), что определяет неравномерное распределение солей в водной толще и является причиной нахождения озера в меромиктическом состоянии (Рогозин, 2015). Очевидно, зообентос, исследованный в 50-е гг., формировался в условиях устойчивой меромиксии и повышенной солености (18-20 г/л). Современному же состоянию зообентоса соответствует более низкое содержание солей ( 16 г/л) и более глубокий уровень перемешивания водной толщи вплоть до перехода в голомиктический режим в 2015 г.

Таким образом, произошедшие в рассматриваемый период изменения в стратификации водоема и его минерализации, очевидно, отразились на общем уровне биомассы и видовом составе бентосного комплекса. Вместе с тем, повсеместное распространение нектобентосного рачка G. lacustris по акватории озера, отмеченное в работе Платоновой (1956), сохраняется и сейчас (Zadereev et al., 2010). 
Таксономический состав сем. Chironomidae, напротив, кардинально изменился за период времени между двумя исследованиями. В середине прошлого века в качестве доминантов среди хирономид были зарегистрированы Procladius sp. и Polypedilum ex. gr. scalanum, а различий в таксономическом составе литорали и профундали отмечено не было (Платонова, 1956). В настоящее время доминирующими видами хирономид о3. Шира являются G. salinus, C. nigrifrons и C. halophilus, тогда как виды вышеупомянутых родов составляют лишь весьма небольшую часть биомассы. Кроме того, современные доминирующие виды неравномерно распределены на разных глубинах: G. salinus присутствует в основном на литоральной части, тогда как представители рода Chironomus составляют основу глубоководного комлекса хирономид. Фенологические наблюдения вылета имаго хирономид также различаются: по данным Платоновой (1956), пик вылета имаго приходился на конец июля-начало августа, а в 2016 г. мы отметили массовый вылет насекомых в первой половине июня. Вероятно, что новые виды-доминанты имеют другие сезонные циклы развития в отличие от доминировавших ранее видов родов Procladius и Polypedilum (The Chironomidae.., 1995).

Мы предполагаем, что существенные изменения уровня биомассы сем. Chironomidae были обусловлены сменой видового состава и выходом на доминирующие позиции видов, адаптированных к изменившимся физикохимическим и трофическим условиям обитания.

G. salinus, доминирующий в составе современного бентосного сообщества оз. Шира, признается аллобионтным видом-двойником вида Glyptotendipes barbipes (Зинченко, 2011; Michailova, 2014), т.е. эти виды различаются лишь по кариосистематическим признакам.
Последний является голарктическим таксоном, встречающимся регулярно и в массовых количествах в различных пресных водоемах Сибири и европейской части России (Кикнадзе, Истомина, 2000). В свою очередь, присутствие G. salinus было отмечено только в соленых и солоноватоводных водоемах Сибири и европейской части Евразии (Айманова и др., 2000; Michailova, 2014; Karmokov, Akkizov, 2016). В соленых и минерализованных водоемах Неарктики (западная и северная части Канады) отмечен значительный вклад в биомассу бентоса вида G. barbipes (Cannings, Scudder, 1978; Moore et al., 1979). Литературные данные свидетельствуют о том, что G. barbipes предпочитает пресные воды либо воды с относительно небольшими уровнями солености, а G. salinus обитает в водоемах с более высокой соленостью (Зинченко, 2011). Состав солей оз. Шира отличается от такового многих других внутренних водоемов и относится к магниево-хлоридному типу. Возможно, что такой солевой состав предпочтителен для G. salinus.

Географическое распространение видовдоминантов глубоководных участков оз. Шира, C. nigrifrons и C. halophilus, различается. C. halophilus (= Chironomus aprilinus Meigen, 1818) считается одним из типичных представителей солоноватоводных местообитаний на всей территории Евразии (The Chironomidae.., 1995; Nazarova, 2006; Zinchenko et al., 2014; Matena et al., 2016). Этот вид, один из немногих, сохранялся в заливах Аральского моря с повышенной соленостью, $>15 \%$ (Nazarova, 2006). Напротив, сведений о присутствии вида $C$. nigrifrons на европейской части Евроазиатского континента в известной нам литературе нет. Вместе с тем данный вид широко встречается на территории Сибири, хотя все находки получены для вод с низкой минерализацией, например водоемы Тувы и 
Горного Алтая (Кикнадзе, Истомина, 2000), заиленные участки верхнего течения р. Енисей (Андрианова, 2013), Иркутское водохранилище (Провиз и др., 2009).

Согласно некоторым исследованиям, увеличение солености внутренних водоемов и водотоков приводит к заметному повышению доли, а иногда и полному доминированию хирономид в составе бентосных сообществ (Hart, Lovvorn, 2005; Zinchenko et al., 2014). При повышении солености более $15 \%$, как правило, происходит значительное снижение видового разнообразия бентоса (Hammer et al., 1990), в том числе и количества видов сем. Chironomidae (Milakovic et al., 2001; Nazarova, 2006). Наши данные согласуются с указанными трендами: в исследованном оз. Шира при современном уровне солености 14-18 г/л основную часть биомассы бентоса (без учета планкто-бентосного вида G. lacustris) составляют хирономиды, а их видовое богатство относительно невелико. В обширном исследовании 18 степных соленых озер в Центральной Канаде показано, что максимальная биомасса зообентоса наблюдалась в водоемах с соленостью около 15 \% (Hammer et al., 1990). Таким образом, гидрохимические условия в оз. Шира можно считать оптимальными для развития зообентоса со специфическим видовым составом.

Среднесезонная суммарная биомасса хирономид оз. Шира на единицу площади была в полтора-два раза выше, чем в соленых реках бассейна оз. Эльтон, расположенных на юге России (Zinchenko et al., 2014). Измеренная нами величина биомассы зообентоса соответствовала диапазону значений, полученному для соленых озер центральной и западной части Канады, 2-68 г/кв.м (Cannings, Scudder, 1978; Hammer et al., 1990), а также для карьерных высокоминерализованных прудов Чехии, 2-10 г/кв.м (Matena et al., 2016).
Вместе с тем биомасса бентосных хирономид оз. Шира была несколько ниже (в 1.5-2 раза), чем таковая в соленых маршах Северной Канады (Milakovic et al., 2001). Можно заключить, что количественные показатели зообентоса изученного озера в целом близки имеющимся в литературе немногочисленным количественным данным для соленых внутренних вод.

\section{Заключение}

Сравнение современных характеристик зообентоса соленого степного оз. Шира с данными, полученными при масштабных исследованиях этого водоема 65 лет назад, выявило, что пространственное распределение биомассы зообентоса по акватории озера в целом сохранилось. Однако за указанный период времени среднее значение биомассы летнего бентоса заметно снизилось, а также произошли резкие изменения в видовом составе хирономидного сообщества. Эти изменения, вероятно, связаны со снижением степени меромиксии озера за последние несколько десятков лет, что привело к смене гидрохимических и трофических условий в донных грунтах. Современными доминантами бентосной фауны оз. Шира являются хирономиды G. salinus, C. nigrifrons и C. halophilus, а также нектобентосные амфиподы G. lacustris. В целом, бентос оз. Шира был представлен небольшим числом таксонов, что соответствует современным представлениям об относительно низком видовом богатстве бентоса внутренних вод с соленостью 15 \%о и выше; при этом средняя биомасса сем. Chironomidae соответствовала диапазону значений, известных для солоноватоводных местообитаний. Выполненные измерения биомассы и продукции комплекса хирономид в дальнейшем послужат основой для оценок потоков биомассы и отдельных 
биохимических веществ при вылете насекомых из воды на сушу прилегающих аридных экосистем, испытывающих дефицит собственной биологической продукции.

Работа поддержана совместным грантом РФФИ-ККФПНиНТД 16-44-240421, грантом НШ-9249.2016.5 Совета по грантам Президента Российской Федерации по государственной поддержке ведущих научных школ, проектом Сибирского отделения Российской академии наук № II.2П/VI.51-1, а также Государственным заданием в рамках программы фундаментальных исследований РФ, тема № 51.1.1.

\section{Список литературы}

Айманова К.Г., Кикнадзе И.И., Андреева Е.Н., Сейсебаев А.Т. (2000) Цитологическая идентификация видов хирономид из водоемов бывшего семипалатинского испытательного полигона. Сибирский экологический журнал, 4: 503-509 [Aimanova K.G., Kiknadze I.I., Andreeva E.N., Seisebaev A.T. (2000) Cytological identification of chironomid species from water bodies of the Semipalatinsk nuclear test site. Siberian Journal of Ecology [Sibirskiy Ekologicheskiy Zhurnal], 4: 503-509 (in Russian)]

Андрианова А.В. (2013) Динамика развития енисейского зообентоса в нижнем бьефе Красноярской ГЭС. Вестник Томского государственного университета. Биология, 21: 74-88 [Andrianova A.V. (2013) Dynamics of development of Yenisei zoobenthos from low reach of Krasnoyarsk Reservoir. Tomsk State University Journal of Biology [Vestnik Tomskogo gosudarstvennogo universiteta. Biologiya], 21: 74-88 (in Russian)]

Голубков С.М. (2000) Функииональная экология личинок амфибиотических насекомых. СПб., ЗИН РАН, 294 с. [Golubkov S.M. (2000) Functional ecology of amphibiotic insect larvae. St. Petersburg, Zool. Inst. Russian Acad. Sci., 294 p. (in Russian)]

Зинченко Т.Д. (2011) Эколого-фаунистическая характеристика хирономид (Diptera, Chironomidae) мальх рек бассейна Средней и Нижней Волги: (Атлас). Тольятти, Кассандра, 258 c. [Zinchenko T.D. (2011) Ecological-faunistical characterization of chironomids (Diptera, Chironomidae) of small rivers from basin of the Middle and Lower Volga River (Atlas). Tolyatti, Kassangra, 258 p. (in Russian)]

Кикнадзе И.И., Истомина А.Г. (2000) Кариотипы и хромосомный полиморфизм сибирских видов хирономид (Diptera, Chironomidae). Сибирский экологический журнал, 4: 445-460 [Kiknadze I.I., Istomina A.G. (2000) Karyotypes and chromosomal polymorphism of Siberian species of chironomids. Siberian Journal of Ecology [Sibirskiy Ekologicheskiy Zhurnal], 4: 445-460 (in Russian)]

Медико-биологические и экологические проблемы курортного комплекса «Шира» (1997) Материалы научно-практической конференции, посвящённой 100-летию организации курорта «Озеро Шира». Томск, ЦНТИ, 146 с. [Medico-biological and ecological problems of resort complex "Shira" (1997) Proceedings of scientific-practical conference dedicated to $100^{\text {th }}$ anniversary of the establishment of "Lake Shira" Resort. Tomsk, CNTI Publishing, 146 p. (in Russian)].

Определитель пресноводных беспозвоночных России и сопредельныхтерриторий. Т. 1 (1994) Цаллолихин С.Я. (ред.) СПб., Издательство ЗИН РАН, 394 с. [Keys for freshwater invertebrates 
inhabiting Russia and adjacent territories. Vol. 1. (1994) Tsallolikhin S.Ya. (ed.) St. Petersburg, Zool. Inst. Russian Acad. Sci., 394 p. (in Russian)]

Определитель пресноводных беспозвоночных России и сопредельных территорий. T. 3 (1997) Цаллолихин С.Я. (ред.) СПб., Издательство ЗИН РАН, 424 с. [Keys for freshwater invertebrates inhabiting Russia and adjacent territories. Vol. 3. (1997) Tsallolikhin S.Ya. (ed.) St. Petersburg, Zool. Inst. Russian Acad. Sci., 424 p. (in Russian)]

Определитель пресноводных беспозвоночных России и сопредельных территорий. T. 4 (1999) Цаллолихин С.Я. (ред.) СПб., Издательство ЗИН РАН, 1000 с. [Keys for freshwater invertebrates inhabiting Russia and adjacent territories. Vol. 4. (1999) Tsallolikhin S.Ya. (ed.) St. Petersburg, Zool. Inst. Russian Acad. Sci., 1000 p. (in Russian)]

Панкратова В.Я. (1983) Личинки и куколки комаров n/сем. Chironominae. Фауна СССР. (Diptera, Chironomidae = Tendipedidae). Ленинград, Наука, 295 с. [Pankratova V.Ya. (1983) Larvae and pupae of midges of subfamily Chironominae. Fauna of USSR. (Diptera, Chironomidae = Tendipedidae). Leningrad, Nauka, 295 p. (in Russian)]

Панкратова В.Я. (1977) Личинки и куколки комаров n/сем. Podonominae и Tanipodinae. Фауна CCCP. (Diptera, Chironomidae = Tendipedidae). Ленинград, Наука, 153 с. [Pankratova V.Ya. (1977) Larvae and pupae of midges of subfamily Podonominae and Tanipodinae. Fauna of USSR. (Diptera, Chironomidae = Tendipedidae). Leningrad, Nauka, 153 p. (in Russian)]

Платонова Л.В. (1956) Донная фауна озера Шира (сообщение 3-е). Ученые записки Красноярского государственного педагогического института, 5: 219-227 [Platonova L.V. (1956) Bottom fauna of Shira Lake (3d report). Scientific Reports of Krasnoyarsk State Pedagogical Institute [Uchenye zapiski Krasnoyarskogo gosudarstvennogo pedagogicheckogo instituta], 5: 219-227 (in Russian)]

Природный комплекс и биоразнообразие участка «Озеро Шира» заповедника «Хакасский» (2011) Непомнящий В.В. (ред.) Абакан, Хакасское книжное издательство, 420 с. [Native community and biodiversity of "Shira lake" area from the "Khakassian" natural reservation. Nepomnyashchii V.V. (ed.) Abakan, Khakassian book press, 420 p. (in Russian)]

Провиз В.И., Бельков С.М., Провиз Л.И., Александров В.Н. (2009) Кариотип и морфология Chironomus nigrifrons Linetsh et Erbaeva, 1971 (Diptera, Chironomidae) из Иркутского водохранилища. Евразиатский энтомологический журнал, 8 (S1): 8-14 [Proviz V.I., Belkov S.M., Proviz L.I., Aleksandrov V.H. (2009) The karyotype and morphology of the Chironomus nigrifrons Linevitsh et Erbaeva,1971 (Diptera, Chironomidae) from the Irkutsk Reservoir. Euroasian Entomological Journal [Evraziatskii entomologicheskii zhurnal], 8 (S1): 8-14 (in Russian)]

Рогозин Д.Ю. (2015) Закономерности стратификации и пространственная динамика фототрофных серных бактерий в меромиктических озерах Хакасии. Автор-т докт. дис. Красноярск, СФУ, 40 с. [Pogozin D.Yu. Mechanisms of stratification and spatial dynamics of phototrophic sulfur bacteria in meromictic lakes of Khakasia. PhD thesis. Krasnoyarsk, Siberian Federal University, 40 p. (in Russian)]

Bartels P., Cucherousset J., Steger K., Eklov P., Tranvik L.J., Hillebrand H. (2012) Reciprocal subsidies between freshwater and terrestrial ecosystems structure consumer resource dynamics. Ecology, 93: 1173-1182

Berezina N.A. (2008) Assessment of predation impact by invasive amphipods in the eastern Baltic Sea. Neobiota, 7: 210-217 
Brodersen K.P., Quinlan R. (2006) Midges as paleoindicators of lake productivity, eutrophication and hypolimnetic oxygen. Quaternary Science Reviews, 25: 1995-2012

Cannings R.A., Scudder G.G.E. (1978) The littoral Chironomidae (Diptera) of saline lakes in central British Columbia. Canadian Journal of Zoology, 56: 1144-1155

The Chironomidae: Biology and ecology of non-biting midges (1995) Armitage P.D., Cranston P.S., Pinder L.C.V. (eds.) Dordrecht, Springer, 572 p.

Contreras-Lichtenberg R. (1999) Revision der westpaläarktischen Arten des Genus Glyptotendipes Kieffer, 1913 (Insecta: Diptera: Chironomidae). Teil 1: Subgenus Phytotendipes Goetghebuer, 1937. Annalen des Naturhistorischen Museums in Wien. Serie B für Botanik und Zoologie, 101: 359-403

Darin A.V., Kalugin I.A., Maksimov M.A., Rogozin D.Yu., Rakshun Ya.V., Darin F.A., Sorokoletov D.S. (2015) Reconstructing the levels of Lake Shira over the last 1500 years with an annual time scale based on data from X-Ray fluorescence microanalysis using beams of synchrotron radiation. Bulletin of the Russian Academy of Sciences: Physics, 79(1): 126-130

Degermendzhy A.G., Zadereev E.S., Rogozin D.Yu., Prokopkin I.G., Barkhatov Y.V., Tolomeev A.P., Khromechek E.B., Janse J.H., Mooij W.M., Gulati R.D. (2010) Vertical stratification of physical, chemical and biological components in two saline lakes Shira and Shunet (South Siberia, Russia). Aquatic Ecology, 44: 619-932

Di Veroli A., Santoro F., Pallottini M., Selvaggi R., Scardazza F., Cappelletti D., Goretti E. (2014) Deformities of chironomid larvae and heavy metal pollution: From laboratory to field studies. Chemosphere, 112: 9-17

Gaevsky N.A., Zotina T.A., Gorbaneva T.B. (2002) Vertical structure and photosynthetic activity of Lake Shira phytoplankton. Aquatic Ecology, 36: 165-178

Gladyshev M.I., Sushchik N.N., Makhutova O.N. (2013) Production of EPA and DHA in aquatic ecosystems and their transfer to the land. Prostaglandins and Other Lipid Mediators, 107: 117-126

Gulati R.D., Degermendzhy A.G. (2002) Preface. Aquatic Ecology, 36: 105-106

Gulati R.D., Mooij W.M., Degermendzhy A.G. (2010) Preface to the Siberian lakes special issue. Aquatic Ecology, 44: 481-483

Hammer U.T., Sheard J.S., Kranabetter J. (1990) Distribution and abundance of littoral benthic fauna in Canadian prairie saline lakes. Hydrobiologia, 197: 173-192

Hart E.A., Lovvorn J.R. (2005) Patterns of macroinvertebrate abundance in inland saline wetlands: a trophic analysis. Hydrobiologia, 541: 45-54

Ji L., Berezina N.A., Golubkov S.M., Cao X., Golubkov M.S., Song C., Umnova L.P., Zhou Y. (2011) Phosphorus flux by macrobenthic invertebrates in a shallow eutrophic lake Donghu: spatial change. Knowledge and Management of Aquatic Ecosystems, 402: 1-13

Karmokov M.K., Akkizov A.Y. (2016) Karyotype characteristics, larval morphology and chromosomal polymorphism peculiarities of Glyptotendipes salinus Michailova, 1983 (Diptera, Chironomidae) from Tambukan Lake, Central Caucasus. Comparative Cytogenetics, 10(4): 571-585

Lake Ecosystem Ecology (2010) Likens G.E. (ed.) Amsterdam, Elsevier, 463 p.

Matěna J., Símová I., Brom A., Novotná K. (2016) Benthic communities in inland salinized waters with different salinities and nutrient concentrations and the ecology of Chironomus aprilinus (Diptera: Chironomidae) in the Czech Republic. European Journal of Entomology, 113: 122-129 
Michailova P.V. (2014) Polytene chromosomes and their significance for taxonomy, speciation and genotoxicology. Short Views on Insect Biochemistry and Molecular Biology, Vol. 1. Chandrasekar R., Tyagi B.K., Gui Z.Z., Reeck G.R. (eds.) International Book Mission Academic Publisher, USA, p. 331353

Milakovic B., Carleton T.J., Jefferies R.L. (2001) Changes in midge (Diptera: Chironomidae) populations of sub-arctic supratidal vernal ponds in response to goose foraging. Ecoscience, 8: 58-67

Moore J.W., Beaubien V.A., Sutherland D.J. (1979) Comparative effects of sediment and water contamination on benthic invertebrates in four lakes. Bulletin of Environmental Contamination and Toxicology, 23: 840-847

Nakano S., Murakami M. (2001) Reciprocal subsidies: Dynamic interdependence between terrestrial and aquatic food webs. Proceedings of the National Academy of Sciences of the United States of America, 98: 166-170

Nazarova L. (2006) Chironomids of the Aral Sea. Chironomus. Journal of Chironomidae Research, 19: 10-12

Reimer J.P., Baerwald E.F., Barglay R.M.R. (2010) Diet of hoary (Lasiurus cinereus) and silverhaired (Lasionycteris noctivagans) bats while migrating through Southwestern Alberta in late summer and autumn. American Midland Naturalist, 164: 230-237

Rogozin D.Y., Genova S.V., Gulati R.D., Degermendzhy A.G. (2010) Some generalizations on stratification and vertical mixing in meromictic Lake Shira, Russia, in the period 2002-2009. Aquatic Ecology, 44(3): 485-496

Rogozin D.Y., Pulyaevskaya M.V., Zuev I.V., Makhutova O.N., Degermendzhi A.G. (2011) Growth, diet and fatty acid composition of gibel carp Carassius gibelio in Lake Shira, a brackish water body in southern Siberia. Journal of Siberian Federal University. Biology, 4: 86-103

Sabo J.L., Power M.E. (2002) River-watershed exchange: effects of riverine subsidies on riparian lizards and their terrestrial prey. Ecology, 83: 1860-1869

Shang J., Zhang L., Shi C., Fan C. (2013) Influence of Chironomid larvae on oxygen and nitrogen fluxes across the sediment-water interface (Lake Taihu, China). Journal of Environmental Sciences, 25: $978-985$

Stenroth K., Polvi L.E., Faltstrom E., Jonsson M. (2015) Land-use effects on terrestrial consumers through changed size structure of aquatic insects. Freshwater Biology, 60: 136-149

Vander Zanden M.J., Gratton C. (2011) Blowin' in the wind: reciprocal airborne carbon fluxes between lakes and land. Canadian Journal of Fisheries and Aquatic Sciences, 68: 170-182

Zadereev E.S., Tolomeyev A.P., Drobotov A.V., Emeliyanova A.Yu., Gubanov M.V. (2010) The vertical distribution and abundance of Gammarus lacustris in the pelagic zone of the meromictic lakes Shira and Shunet (Khakassia, Russia). Aquatic Ecology, 44: 531-530

Zinchenko T.D., Gladyshev M.I., Makhutova O.N., Sushchik N.N., Kalachova G.S., Golovatyuk L.V. (2014) Saline rivers provide arid landscapes with a considerable amount of biochemically valuable production of chironomid (Diptera) larvae. Hydrobiologia, 722: 115-128 